\title{
Statistical Analysis of the Impact of Selected Factors on the Rate of Accidents
}

\section{R. Budský*}

AZIN CZ s. r. o., Prague, Czech Republic

*Corresponding author: budsky.roman@volny.cz

M. Koucký**

**Corresponding author:miroslav.koucky@tul.cz

\begin{abstract}
The main purpose of this statistical analysis was to find objective relationships between the indicators of traffic accidents in selected European countries and the factors which are no doubt important for the safety of road traffic, for example, general prevention of accidents and the relevant requirements of the road traffic regulations, training and examination of new drivers, the post-examination period, sanction system, technical parameters of roads and vehicles, and, last but not least, the influence of important social climates. In the assessment of the results, the index of corruption perception was also considered, which has proven an important modifier of influence of the mentioned key factors.
\end{abstract}

KEY WORDS: Road accidents, analysis, influencing factors, index of corruption perception.

\section{THE SPECIFICATION AND OBJECTIVES OF THE ANALYSIS}

The objective of the analysis was to assess, within the project of the Ministry of Transport Nr. 1F54L/033/160, "The stationary complex system of driver education and motivators for traffic rules observance on highways and roads" in an objective manner, i.e., using mathematical and statistical methods dependant on the rate of accidents, quantified by the number of fatal injuries in traffic accidents on the following selected (so-called explanatory) factors (the mentioned analysis serves at the same time for work on the project of the Ministry of Transport Nr. CG711-014-160 "Methods and tools for increasing the reliability of the human factor in highway traffic safety in the Czech republic"):

- General prevention and road traffic regulations

- Training

- Examination of new drivers

- Post-examination period

- Sanctions

- Roads and vehicles (technical parameters)

- Social events

The analysis has been carried out based on the data on the rate of accidents in nine selected EU countries (the CR, Spain, Great Britain, Greece, Hungary, the Netherlands, Portugal, Sweden and Slovenia) during the period from 1970 to 2005. 


\section{INPUT DATA}

The statistical data on the rate of accidents have been taken from the following defined official sources. Qualitative assessment of the considered explanatory factors has been obtained in the form of an expert assessment, in particular from inputs received from the project SUNFLOWER+6 (www.sunflower.swov.nl).

\subsection{ORGANIZATION}

\subsubsection{CENTRE OF TRAFFIC RESEARCH}

The website of $\operatorname{CDV}^{1}$ (www.cdv.cz) contains a large amount of statistical data concerning accidents on roads. Data are publicly available for the period 1995 - 2002.

\subsubsection{IRTAD (INTERNATIONAL TRAFFIC SAFETY DATA AND ANALYSIS GROUP)}

Data about the number of fatal injuries per 100000 citizens in each of the nine considered countries are available on the website of $\operatorname{IRTAD}^{2}$ (www.irtad.net).

\subsection{ANALYZED DATA}

For the purpose of the analysis, each of the nine assessed countries is characterized by:

- The time line determining the number of fatal injuries per 100000 citizens (graph, table);

- The explanatory factors characterizing the environment - expert assessments;

Those qualitative factors are included in the original study in the form of a table specifying changes in the environment in each of the 9 monitored countries during $1970-2005$.

For the assessment of issues in each country during the monitored period, the data received from the conclusions of the research task SUNFLOWER+6 were used, as defined above specific data for each country are provided in the final study of the TWIST project in the appendix at the end of this study.

\section{STATISTICAL ANALYSIS}

The analysis of the relationship between the rate of accidents and selected factors has been carried out on a sample of 9 EU countries - the Czech Republic, Spain, Great Britain, Greece, Hungary, the Netherlands, Poland, Sweden and Slovenia. It is based on a time line containing data from the period 1970 - 2000 specifying:

- The development of the rate of accidents expressed by the number of fatal injuries per $100000 \mathrm{~km}$;

\footnotetext{
${ }^{1}$ Varujicí vývoj dopravní nehodovosti na silnicich $v \check{C} R$ ve srovnání se zahraničím

URL: <www.cdv.cz> [cit. 2005/07/15]

${ }^{2}$ Selected Risk Values

URL: <http://cemt.org/IRTAD/IRTADPUBLIC/we2.html> [cit. 2008/03/03]
} 
- Qualitative levels of individual explanatory factors - general prevention and road traffic regulations; training; examination of new drivers; post-examination period; sanction system; roads and vehicles; social climate.

For example, the data concerning the Czech Republic are as follows ${ }^{3}$ :

Table 1: Influence on Road Safety

\begin{tabular}{|c|c|}
\hline No influence & \\
\hline Small (positive) influence & S \\
\hline Big positive influence & B \\
\hline Negative influence & N \\
\hline
\end{tabular}

Table 2: Qualitative levels of individual explanatory factors (Czech Republic)

\begin{tabular}{|l|c|c|c|c|c|c|c|c|c|c|c|c|}
\hline Explanatory factor / year & $\mathbf{6 5}$ & $\mathbf{6 8}$ & $\mathbf{7 0}$ & $\mathbf{7 1}$ & $\mathbf{7 2}$ & $\mathbf{7 4}$ & $\mathbf{7 8}$ & $\mathbf{8 9}$ & $\mathbf{9 0}$ & $\mathbf{9 1}$ & $\mathbf{9 7}$ & $\mathbf{0 1}$ \\
\hline $\begin{array}{l}\text { General prevention and } \\
\text { road traffic regulations }\end{array}$ & & & & & & B & B & & N & & B & B \\
\hline Training & & & & & & & & & & B & & S \\
\hline Examination of new drivers & & & & & & & & & & & & N \\
\hline Post-examination period & & & & & & & & & & & & S \\
\hline Sanction system & & & & & & & & & & & & N \\
\hline Roads and vehicles & S & & & & & & & & & & & \\
\hline Social climate & & N & N & N & N & & & N & N & N & & \\
\hline
\end{tabular}

For comparison, data on Sweden are as follows:

Table 3: Qualitative levels of individual explanatory factors (Sweden)

\begin{tabular}{|l|l|l|l|l|l|l|l|l|l|l|l|l|l|l|l|l|}
\hline Explanatory factor / year & $\mathbf{7 2}$ & $\mathbf{7 5}$ & $\mathbf{7 6}$ & $\mathbf{7 7}$ & $\mathbf{7 8}$ & $\mathbf{7 9}$ & $\mathbf{8 0}$ & $\mathbf{8 1}$ & $\mathbf{8 2}$ & $\mathbf{8 3}$ & $\mathbf{8 4}$ & $\mathbf{8 5}$ & $\mathbf{8 6}$ & $\mathbf{8 7}$ & $\mathbf{8 8}$ & $\mathbf{8 9}$ \\
\hline $\begin{array}{l}\text { General prevention and } \\
\text { road traffic regulations }\end{array}$ & B & B & & B & S & S & S & B & B & S & & S & B & B & B & S \\
\hline Training & & & & & & & & S & B & & B & & & & & \\
\hline Examination of new drivers & & & B & & & & & & B & & B & & & & & \\
\hline Post-examination period & & & & & & & & & & & & & & & & \\
\hline Sanction system & & & & B & & & & & & & & & & & & \\
\hline Roads and vehicles & & & & & & & & & & & & & & & & \\
\hline Social climate & & & & & & & & & & & & & & & & \\
\hline
\end{tabular}

${ }^{3}$ http://sunflower.swov.nl/ SUNflower +6 - A comparative study of the development of road safety in European countries 


\begin{tabular}{|l|c|c|c|c|c|c|c|c|c|c|c|c|c|}
\hline \multicolumn{1}{|c|}{ Explanatory factor / } & 90 & 91 & 92 & 93 & 95 & 96 & 97 & 98 & 99 & 00 & 01 & 02 & 03 \\
\hline $\begin{array}{l}\text { General prevention and } \\
\text { road traffic regulations }\end{array}$ & & & B & B & & S & B & S & B & S & & & \\
\hline Training & B & & & S & & & & & & & & & \\
\hline Examination of new drivers & B & & & & & & & & & & & & \\
\hline Post-examination period & B & & & & & & & & & & & & \\
\hline Sanction system & B & S & B & B & & & & & & & & B & \\
\hline Roads and vehicles & & & & & S & S & & & & & S & & B \\
\hline Social climate & & & & & & & & & & & & & \\
\hline
\end{tabular}

And finally, the development of the rate of accidents, expressed by the number of fatal injuries per 100000 inhabitants (comparison between the Czech Republic and Sweden):
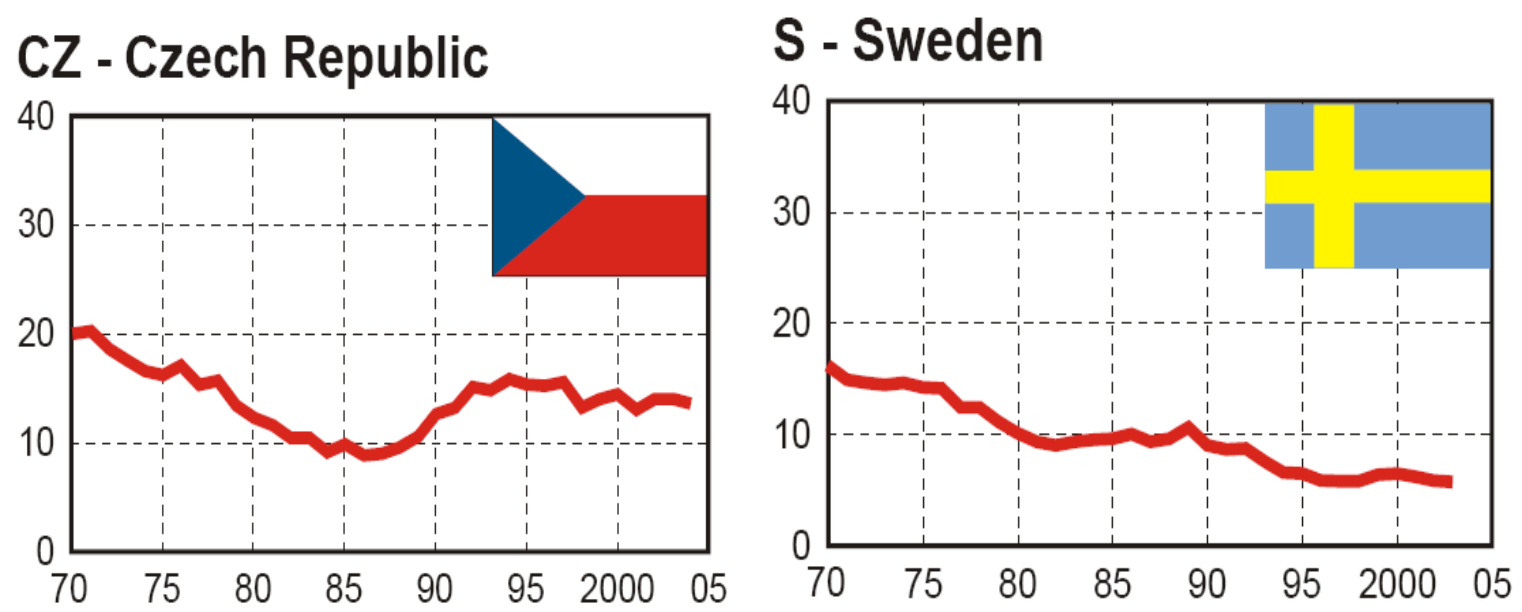

\section{Graph 1: The development over time of the rate of accidents and explanatory factors}

The input data shown above were available in a form which required, before the analysis itself, relatively wide pre-processing (quantification of factors, weighing of factors and countries, various transformations of data, etc.) which is not a part of this version of the submitted report. From a mathematical point of view, methods of non-parametric correlation analysis were used for processing, resulting in the following conclusions:

- The selected explanatory factors determine in a decisive manner the rate of accidents, and it is not therefore necessary to consider an introduction of other explanatory factors. This fact is obviously demonstrated, not only by the following graph No 2, but it is also objectively achievable by exact statistical methods - more than $90 \%$ of all changes in the rate of accidents can be clarified just using the considered explanatory factors. 


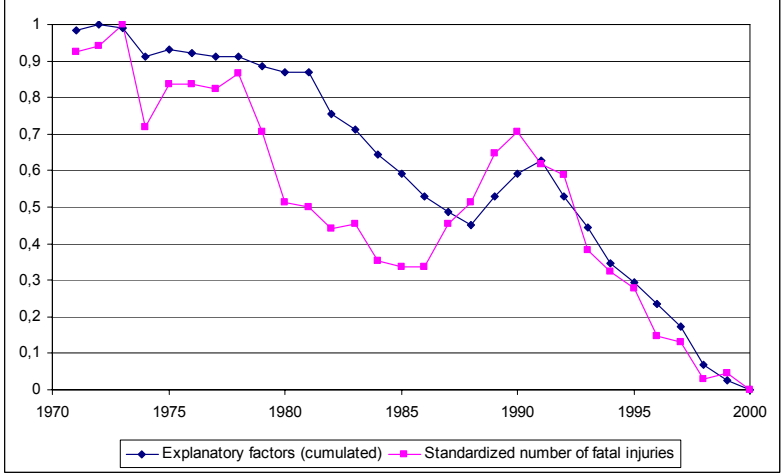

\section{Graph 2: The development over time of the rate of accidents and explanatory factors}

- The analysed data have proven that the following group of explanatory factors has a decisive influence on the rate of accidents - sanctions system, general prevention and relevant requirements of the road traffic regulations, roads and vehicles, and the social climate. The influence of other factors (the level of training, examination of new drivers, post-examination period) cannot be considered as demonstrative.

- An internal classification of the sanctions factored into several components allows for the identification of fundamental components. In this regard, the following have proven fundamental - the quality of imposed sanctions (the amount of fines, point system, banned driving, progressive rates in the case of repeated delinquency, existence of discouraging sanctions for especially unwanted delinquency), the quality of the method and consistence of enforcing the sanctions (communication between the Police and the acting authority, a progressive increase in sanctions, etc.) and the quality of bodies dealing with delinquencies.

- The influences of the social climate and its changes on the rate of accidents are important. For example, "fast" democratising processes in post-communist countries negatively influenced the rate of accidents, in particular in the Czech Republic. Another argument documenting the importance of this explanatory factor is the surprisingly high value of the determination coefficient expressing the relationship between the index of corruption perception and the rate of accidents, this time expressed as the number of fatal injuries per road kilometres in selected countries - Austria, Belgium, Czech Republic, Germany, Denmark, France, Finland, Great Britain, Ireland, Norway, the Netherlands and Sweden - see the following graph No 3.

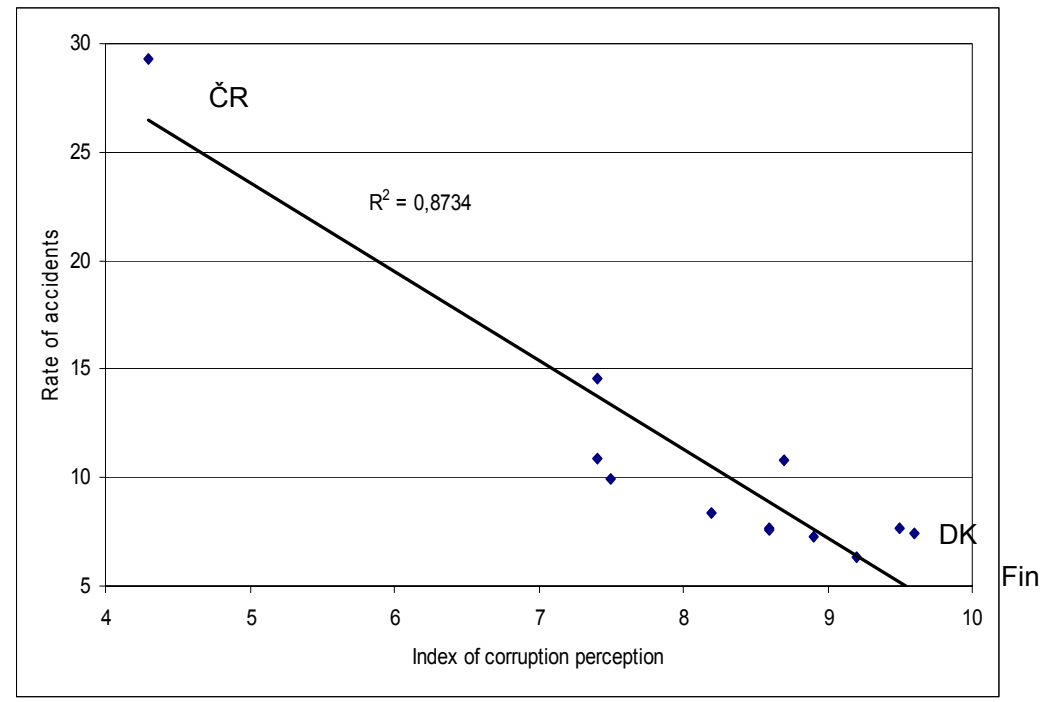

Graph 3: The relationship between the rate of accidents and the index of corruption perception 
- Another identified factor is the fact that events negatively influencing the rate of accidents do not have an entirely recurrent nature and show certain inertia. For example, the poorer moral of drivers resulting from social changes, a low quality sanctions system, etc., have a stronger negative influence on the rate of accidents than the "reverse" changes with positive influence - there is no "return" to the original status.

- In addition to the influence of the aforementioned main explanatory factors, attention in the analysis was also paid to the assessment of the influence of some specific characteristics of training - the necessity to undergo at least a part of the driving training with a professional driving school, the obligation of a basic preparation of teachers, existence of a control system of teachers and driving schools, a minimum number of obligatory hours of practical driving training, the real number of undergone driving training hours, the length of the practical examination and the existence of a testing period. In this regard it is possible to state that none of the mentioned characteristics of training has proven a statistically significant influence on the rate of accidents expressed in the number of fatal injuries per the selected number of citizens, respective per the selected number of road kilometres (the same conclusions are valid for the number of injured persons in traffic accidents).

\section{REFERENCES}

Hendrix et al. 2001. Guide on Driver Licencing. 1st edition Brussels: Commission Internationale des Examens de Conduite Automobile, 2001. ISBN 90-76408-10-6.

http://sunflower.swov.nl SUNflower+6 - A comparative study of the development of road safety in European countries.

Traffic deaths per 100000 population since 1970

URL:<http://www.cemt.org/IRTAD/IRTADPUBLIC/we2.html> [cit. 2008/03/03]

Selected Risk Values

URL: <http://cemt.org/IRTAD/IRTADPUBLIC/we2.html> [cit. 2008/03/03]

Varující vývoj dopravní nehodovosti na silnicích v ČR ve srovnání se zahraničím

URL: <www.cdv.cz> [cit. 2005/07/15] 